regulation will be practised only by a fortunate few, but the criteria of selection is likely to be vitality and capacity to love, both symptoms of psycho-somatic health.

Paul Ritter

7 Magdala Road, Nottingham.

IT may well be that enthusiasm on the part of the parents is a more essential condition than are any material circumstances for carrying out 'self-regulation' in the family successfully. Nevertheless, the success of this procedure can be adequately assessed only from studies made by independent psychological observers of a fair sample of such families and of the personal and social adjustment of the children.

\section{D. Vernon}

The University, Reading.

\section{MISCELLANY}

\section{The Problem of Language in Publications of Works in Scientific and Other Fields of Learning}

The predominance of the English language in modern scientific and technical literature, of which the research workers and writers of reviews are well aware, was clearly demonstrated in an important report published by Unesco ${ }^{1}$ on different aspects of the language problem in science and technology. It would indeed be interesting to obtain similar information on published works in other fields of knowledge.

The problem of language is not a new one and has been discussed by men of learning at different times. Significant and prophetic in this respect was the letter ${ }^{2}$ by David Hume to Gibbon dated October 24 1767. It concerns one of the early attempts by Gibbon to write a historical essay which he devoted to the history of the Swiss Republic. In the selection of this subject he was influenced by his Swiss friend Deyverdun and the feeling he had for Switzerland as his country by adoption. He began to work on this essay in 1764 when, as he wrote: "The Decline and Fall of Rome I still contemplated at an awful distance. ...".

"It is but a few days ago," wrote Hume, "since Deyverdun put your manuscript into my hands, and I have perused it with great pleasure and satisfaction. I have only one objection derived from the language in which it is written. Why do you compose in French, and carry faggots into the woods, as Horace says with regerd to Romans who wrote in Greek? I grant that you have a like motive to those Romans, and adopt a language much more generally diffused than your native tongue : but have you not remerked the fate of those two ancient languages in following ages ? The Latin, though then less celebrated, and confined to more narrow limits, has in some measure outlived the Greek, and is now more generally understood by men of letters. Let the French, therefore, triumph in the present diffusion of their tongue. Our solid and increasing establishments in America, where we need less dread the inundation of Barbarians, promise a superior stability and duration to the English language.
"Your use of the French tongue has also led you into a style more poetical and figurative, and more highly coloured, than our language seems to admit of in historical production. ...."

Reflecting on some defects of his essay, Gibbon wrote $\theta^{2}$ :

"My ancient habits, and the presence of Deyverdun, encouraged me to write in French for the continent of Europe ; but I was conscious myself that my style, above prose and below poetry, degenorated into a verbose and turgid declamation. Perhaps I may impute the failure to the injudicious choice of a foreign language. Perhaps I may suspect that the language itself is ill adapted to sustain the vigour and dignity of an important narrative. . . ."

One may ask to what extent Hume's letter and these reflexions influenced Gibbon, when he was ready for his work on the "Decline and Fall of the Roman Empire", in adopting for it a language more suitable "to sustain the vigour and dignity of an important narrative" 2 . Hume's letter reflected no prejudice on his part against France, where he lived for several years, enjoying the friendship of many distinguished persons, and where he found more admirers than in his own country ${ }^{3}$. On the contrary, this letter illustrates the generally accepted unrivalled position then occupied by the French language among men of learning, a position which had already been recognized before Hume's time and which was held for almost a century following his letter to Gibbon. Educated people and scholars of different countries read in French the works of the great French philosophers, writers and scientists, and many of them could write and speak in French as well as in their mother tongues. It is therefore not surprising that many of the universally admired works of learning both in science and letters, published in France from the beginning of the eighteenth until the middle of the nineteenth century, were not translated into other languages, including English.

The fact that the English language is on the way to occupying, at least in some respects, the position previously held by the French language, fulfils Hume's prophecy beyond anything he could have contemplated, especially if we consider the rapidly growing activity in different fields of learning and the production of works of marked scholarship in the country which he referred to as our "solid and increasing establishments in America".

Although there is no sign yet that the prevalent use of the English language is abating, or has even reached its peak, one must not forget Hume's remark as to the fate of other, once dominant, languages. Moreover, the prevalence of one language does not necessarily imply a loss of interest in the others. On the contrary, this interest, being freed from more practical purposes, will not cease to be stimulated by the desire to appreciate and enjoy more fully the cultural life of the corresponding country, which can scarcely be satisfied without the knowledge of its language.

\section{KEILIN}

Molteno Institute, University of Cambridge.

1 "Scientific and technical translating and other aspects of the language problem". Documentation and Terminology of Science. Unesco. (Atar, Genève, 1957).

2 "The Miscellaneous Works of E. Gibbon, with Memoirs of His Life and Writings", edit. by Lord Sheffield, in 5 vols. Vol. 1 "Memoirs and Letters

${ }^{3}$ Greig, J. Y. T., “David Hume” (.Tonathan Cape, London, 1931). 